\title{
Citizenship Rights and the Development Paradigm in North-East India
}

\author{
Hiramani Patgiri \\ Research Scholar, Department of Political Science, Gauhati University, Assam, India
}

\begin{abstract}
The right of citizenship is an important right in every democratic political country. As a member of the political community, a citizen is provided with certain rights to fulfil his aspirations and to develop his personality to the fullest extent. In a democratic country like India, after the adoption of the Constitution, several rights were granted to the citizens of the country. The government tried to act as a welfare agency in the life of the human beings. However, the development initiatives taken by the Government of India in the postindependent period, present a different picture before us. People are denied their citizenship rights. The present initiatives taken by the Government of India transform the North-East into country's future power hub is significantly denying the people of the region from their basic rights including right to security of life, healthy environment, and livelihood and depriving of them from their community life. This article is an illustration of the evil effects of development initiatives in the life of the people of North-East India.
\end{abstract}

Keywords: citizenship, development paradigm, displacement, livelihood and security.

\section{Introduction}

The concept of citizenship is presently occupying significant position in the Social Science discourse. Citizenship is one of the most commonly used terms in a democracy. It is used at all levels of politics; in formal legal documents, in laws and in constitutions. Citizenship is the core to the functioning of a democratic political system. These concepts are gaining so tight grip to threaten the very existence of democratically elected governments. In present time, these concepts of citizenship rights is discussed and debated very frequently. A major issue related with citizenship is the development paradigm. The inter-relationship between development and citizenship has wider implications in India. In the post-independent time, the development paradigm adopted by the government of India, in many instances violated the right to citizenship guaranteed under the Constitution of India. Specially, in North-East India the development policies and programmes have emerged as a major curse towards the citizens of this region. This article will try to highlight the problems faced by the people of North-East under development initiatives taken by the central and the state government.

\section{Citizenship: Basic Idea}

Citizenship is very a wide and complicated concept. Citizenship has been defined as the legal status of membership in a political community. This legal status signified a special attachment between the individual and the political community. In general, it entitled the citizenship to whatever prerogatives and responsibilities that were attached to membership. With the creation of the modern state, citizenship came to signify certain equality with regard to the rights and duties of membership in the community. The modern state began to administer citizenship; it determines who gets citizenship, what the associated benefits are, and what rights and privileges it entails. As a legal status, citizenship has come to imply a unique, reciprocal, and unmediated relationship between the individual and the political community. Citizenship, in short, is nothing less than the right to have rights. As citizen, a person enjoys three basic rights: civil, political, and economic. Civil rights are necessary for individual freedoms and are institutionalised in the law courts. Political citizenship guarantees the right to participate in the exercise of political power in the community, either by voting, or by holding political office. Economic rights enable citizens to earn their livelihood essential for him and for his family.

\section{Citizenship And The Indian Constitution}

As the member of the political community i.e. the state, the Indian Citizens also enjoy a wide range of freedom and rights guaranteed under Indian Constitution. Article 21 of the Constitution guaranteed "Right To Life" with dignity to its citizens. In several cases the Supreme Court has held that it is not confined to physical existence but includes in its ambit every citizen's right to a life with dignity. It includes all necessities such as adequate nutrition, shelter, work and other facilities. Thus, Article 21 ensures security of a person's livelihood. This right is mentioned also in international covenants. For example, Article 1 of the International Covenant on Economic, Social and Cultural Rights that came into force on January 3, 1976 says that all peoples have a right to self-determination. By its virtue they determine freely their political status and pursue their economic, social 
and cultural goals. They enjoy freedom in their life. They can adopt any kind of livelihood in their life. Their social and community life with cultural variety has been accepted by the Constitution. The incorporation of "Fundamental Rights" added new meaning to such provisions. The "Right to Development" has also been accepted in the Constitution of India.

\section{Citizenship And The Development Paradigm}

The relationship between development and citizenship is very complicated. In the post-independent era, the Indian government adopted the path of capitalist development in India. The main motive of the Indian government was to achieve development for the country which is very pathetic due to colonial exploitation continued for a long period of time. These development initiatives are generally carried out to improve the living standards of the citizens of the country and to provide them with new opportunities for further development in their life. The right to Citizenship has been provided and various provisions were created to ensure their dignity of life

In the post-colonial era, the government of India initiated various development projects. But as a contrary to such development programmes, people's rights are being violated by the state. Here, comes the issue of "Citizenship Rights" which challenges the notion of "State". In modern times, the state has assumed the role of a welfare state. The prime function of the state is considered to bring development for the people, provide them with the basic security issues of their day-to-day life and make provisions for further development in their life. Therefore, to bring out an overall development in the life of the citizens is considered to be the main responsibility of the modern state; which is in complete contrast to the ancient role of the state where the state mainly played the role of a "Police State" in which the state basically exists to protect peace and order in society. The role of the state expands with the passing of time and state has to carry out development policies for the benefit of the people. But the development policies or programmes are not free from criticism. As an evil effect of these policies, the general masses have to suffer for whom the policies are initiated.

Internal Displacement of Persons (IDPs) is such a phenomenon which is creating major threats towards the very existence of human life. The development induced displaced people not only lose their identity, but their livelihood also. In such a situation, they lose their belief in the state. They feel deprived from the very notion of state and are driven by psychological trauma. And due to such deprivation, they rise in revolts against the state. Thus, the state has to face resistance from its own people as it fails to carry out its duties and responsibilities. Development as a special activity needs reorganisation of lends for which lands have been acquired from the common masses. As a result, they are displaced from their places of residence. In particular these events have drawn attention to the number and type of persons that development projects have displaced (DP) or deprived of livelihood without physical relocation, to the eminent domain according which people are displaced without their consent. And all the land acquisitions have been done under the "Land Acquisition Act" (1894) which is itself is a colonial act introduced by the British government to entertain their colonial interests. Its focus is on the economic security of the State at the cost of a section of its citizens and that people become insecure in order to protect the country's security. Development of every citizen was the objective of postindependence planning but there are indications that in reality greater emphasis was laid on economic growth than on its benefits reaching every citizen. The dominant development paradigm suggested the use of the natural resources for projects such as mines, dams, industries, nuclear installations and military bases. They acquired land that people inhabited and in the name of national development, displaced some and deprived others of their land and sustenance without physical relocation.

It happens because the Land Acquisition Act 1894 (LAQ) that is an enabling Act for land acquisition is based on the eminent domain of the State. Its first facet is that it recognises only individual property. All biodiversity and what does not have an individual title is State property. Its second facet is that the State alone has the right to define a public purpose and deprive even individual property owners of their assets in its name. Displacing them by giving limited information is intrinsic to the eminent domain and it is the first step in the trauma and insecurity that it causes. The law demands only formal information through a notification in two newspapers but not that the State ensure that the information reaches the persons to be affected by it. The situation is worse when it comes to common property resources (CPRs) on which a large number of the DPs/PAPs depend. But the law treats them as State property and its dependants as encroachers. They do not have to be informed about their displacement since the State is considered their owner. Many such communities have lived on that land for more than a thousand years and have developed a symbiotic relationship with it. But many of them are not even counted among the DP/PAP. That causes immense insecurity among the CPR dependants. More than in the post, the definition of the public purpose brings the CPR dependants in direct conflict with the State particularly with the onset of neo-liberal globalisation when "public purpose" is used increasingly to serve private corporate interests. Land acquisition has deprived several lakhs of families of their livelihood. A table can be shown to verify this point. 
Table

\section{A CONSERVATIVE ESTIMATE OF DPS AND PAPs, 1951-1990 (IN LAKHS)}

\begin{tabular}{|c|c|c|c|c|c|c|}
\hline Project Type & Dams & Mines & Industries & Wildlife & Others & $\begin{array}{l}\text { Total In } \\
\text { Lakhs }\end{array}$ \\
\hline All DPs in Lakhs & 164.00 & 25.50 & 12.50 & 06.00 & 05.00 & 213.00 \\
\hline$\%$ & 77.00 & 12.00 & 05.90 & 02.80 & $\mathbf{0 2 . 3 0}$ & 100.00 \\
\hline Resettled & 41.00 & 06.30 & 03.75 & 01.25 & 01.50 & 53.80 \\
\hline$\%$ Of DPs & 25.00 & 24.70 & 30.00 & 20.80 & 30.00 & 25.00 \\
\hline Back Log in Lakhs & 123.00 & 19.20 & 08.75 & 04.75 & 03.50 & 159.20 \\
\hline$\%$ 0f DPs & 75.00 & 75.30 & 70.00 & 79.20 & 70.00 & 75.005 \\
\hline Tribal DPs in Lakhs & 63.21 & 13.30 & 03.13 & 04.50 & 01.25 & 85.39 \\
\hline \% of All DPs & 38.50 & 52.20 & 25.00 & 75.00 & 25.00 & 40.00 \\
\hline Resettled & 15.81 & 03.30 & 00.80 & 01.00 & 00.25 & 21.16 \\
\hline$\%$ of Tribal DPs & 25.00 & 25.00 & 25.00 & 22.00 & 20.00 & 25.00 \\
\hline Back Log & 47.40 & 10.00 & $\mathbf{0 2 . 3 3}$ & 03.50 & 01.00 & 64.23 \\
\hline \% of DPs & 75.00 & 75.00 & 75.00 & 78.00 & 80.00 & 75.00 \\
\hline
\end{tabular}

(Source: Fernandez 1994: 24 and 32)

\section{The North-East India}

Northeast India, consisting of the seven states of Assam, Arunachal Pradesh, Manipur, Meghalaya, Mizoram, Nagaland and Tripura is known for its biological and cultural diversity and the unique Brahmaputra and Barak river systems. While the seven states are indeed collectively referred together as the 'Northeast', there is substantial diversity within the region even as far as political and socio-economic issues are concerned, both historically and in contemporary times. The region is rich in biodiversity and is home to important populations of wildlife species. The issue of citizenship rights in the development paradigm has become relevant to the Northeast more than in the past, because the focus of people displacing schemes has shifted to this region in recent time. Major hydro-electric dams were planned to construct in "Seven-Sisters" which will displace the people from their places. These and other schemes raise questions about the people's right to a life with dignity. The intention of the central government to transform the North-East India into power hub raised serious question on the displacement of the people.

In 2001, the Central Electricity Authority (CEA) did a preliminary ranking study of the hydroelectric potential of various river basins in the country. The Brahmaputra basin was given the highest 'marks' and 168 projects with a total installed capacity of $63,328 \mathrm{MW}$ were identified. The tag of being the country's 'future powerhouse' has been proactively used for the region since the Northeast Business Summit in Mumbai in July 2002. The 50,000 MW Hydro Initiatives launched by the Ministry of Power in 2003 also has a major focus on the Northeast. The 'Pasighat Proclamation on Power' adopted in January 2007 at the North East Council's Sectoral Summit on the Power Sector identifies the region's hydropower potential as one of the priority areas to contribute to the country's energy security. The push for large hydropower projects in the Northeast was primarily a process driven by the Central Government till the gradual liberalisation of hydropower policies allowed states to invite private players. While Sikkim kick-started this process in the Northeast in 2001-02, the process gathered momentum across the region in 2005.

The debate over CPRs is also an important issue in North-East. With the power projects implemented since the 1960s, such as the Umium Hydro-electric dam near Shillong, thermal plants at Bongaigaon, Chandrapur and Namrup in Assam and the Dumbur dam in Tripura that have displaced several thousand families. Also the oil sector, industries and urbanisation have caused displacement. Besides, the real number of DP/PAP may be hidden because most land acquired is CPRs. Many dams are being planned in areas falling under the Sixth Schedule of the Constitution or its equivalent customary law that recognises community ownership, thus contradicting the colonial principle of eminent domain on which land laws in India are based. For example, oil and coal are the only known explorations for minerals in the region and in recent years, uranium in Meghalaya where the Government has begun the initial survey. Land in Meghalaya comes under the Sixth Schedule. Thus their social norms contradict the eminent domain. While the State sees uranium as a vital component of its "scientific nuclear project", it cannot begin mining it because land belongs to the indigenous communities. For four years, the government and the people have been locked in an impossible battle.

A careful perusal of the ground situation indicates that displacement, particularly of livelihoods and rights is grossly underestimated in these projects. Azing Pertin of the Siang Peoples Forum in Arunachal Pradesh says "Since our state is hilly, there is very little land where permanent cultivation is possible. Virtually all our available arable lands will be submerged by the 2700 MW Lower Siang project in the affected area in the Siang Valley. The magnitude of impact has to be understood keeping this context in mind. It is misleading to argue that the land being lost is a small percentage of the total area of the district or state and wrongly assume that the project is benign." 
Shifting agriculture (jhum) is a dominant traditional land use in the hills of Northeast India and plays a critical role in the livelihoods of people, maintaining agricultural biodiversity and providing food security. Increasing pressures on land have resulted in the shortening of jhum cycles (the length of the fallow period between two cropping phases), thus impacting the ecological viability of this farming system. The submergence of land by hydel projects will further shorten the jhum cycle and enhance the pressure on the surrounding areas, thus affecting the environment and the livelihoods of jhum-dependent communities over a much larger landscape.

A major catalyst to trigger the larger debate on downstream impacts of dams in Assam, has been the repeated incidents of dam-induced floods across the state from upstream projects (e.g. 405 MW Ranganadi in Arunachal Pradesh) in recent years. Downstream impact concerns raised in the Northeast include: loss of fisheries; changes in beel (wetland) ecology in the flood plains; impacts on agriculture on the riverine islands and tracts); impacts on various other livelihoods due to blockage of rivers by dams (e.g. driftwood collection, sand and gravel mining); increased flood vulnerability due to massive boulder extraction from river beds for dam construction and sudden water releases from reservoirs in the monsoons; dam safety and associated risks in this geologically fragile and seismically active region. The Brahmaputra valley, a thickly populated narrow strip of land with hills surrounding it, has awoken to the fact that it is going to be increasingly vulnerable to risks from existing and proposed large dams upstream. This realization has been significant for a civilisation whose cultural identity customs, food habits, music, religious beliefs - is inextricably linked to its river systems. People of Assam have been raising concerns about dam-induced floods in downstream areas due to hydropower projects like Ranganadi, Umtru, Karbi-Langpi, Kopili, and Kurich.

Gita Bharali, in her article "Development-Induced Displacement and Human Security In Assam" mentions that the projects have caused 50-60 million DP/PAP in post-colonial India, the biggest number of them of dams. Only $25 \%$ of the DPs have been resettled partially, some have got niggardly compensation and others have been ignored. Thus, most of them have been impoverished and marginalized in the name of national development, have been pushed into a situation of insecurity and have lost their right to a life with dignity. In such a situation, state failed to provide human security. Human security is the totality of the social, economic and other components. Article 21 of the Constitution speaks of right to life. In several cases the Supreme Court has held that it is not confined to physical existence but also includes in its ambit every citizen's right to a life with dignity. It includes all necessities such as adequate nutrition, shelter, work and other facilities. Thus, Article 21 ensures security of a person's livelihood. In practice, however, one witnesses a breakdown of such provisions through acts like development-induced displacement that denies human security to the project DP/PAP by alienating them from their land and livelihood without their consent. In most cases they are not even informed of the alienation of their livelihood.

The disjunction between the interests of the State and those of the DP/PAP and the insecurity it causes in the latter came out clearly in the Assam displacement study. By official count the State used around 3.9 lakh acres of land for development 1947-2000. It affected some 400,000 persons. In practice the total is a little over 14 lakh acres that caused more than 19 lakh DP/PAP. The more than 10 lakh acres that are not counted are CPRs that the State considers its property that is transferred from one department to another. It considered its inhabitants encroachers whom it did not have to count among the DP/PAP. Little wonder then, that more than $50 \%$ of them are tribals who are $12.4 \%$ of the population (Fernandes and Bharali 2006). In other States too much of the land will be tribal CPRs, for example the proposed Tipaimukh dam in Manipur that will use the CPRs of the Zeliangrong Naga, Hmar and Kuki tribals.

All these developments possess a major threat to the livelihood pattern of the people. Development induced displacement denies to the displaced persons from their access to natural resources on which the entire community depends. They are denied their security around the CPRs by treating them only as State Property and ignoring their dependants, thus taking away their source of food and income and pushing them into a situation of economic insecurity. Landlessness and joblessness increase after it and result in occupational shift from cultivation to daily wages, domestic work and other types that deny them the security of sustenance. Thus, impoverishment is the consequence of depriving the people of their livelihood.

The impact of development projects is not limited to the economic field but impinges on the social and cultural aspects. Deprivation leads the DP/PAP into insecurity by uprooting their communities and entire villages and thereby destroying long established social networks. The DPs/PAPs who live in an Informal society are forced to interact with another culture and society to which they cannot always adapt themselves. Such insecurity results in marginalization. . It fragments and destroys communities, social organisations, kinship groups and the social order. Without preparing the DP/PAP face the new order, lose the security they had within the social structure of their community or clan and are forced to adjust themselves to the host population. Another is the problem of food security that is faced by the displaced persons after the loss of land and forests. The DP/PAP also faces the problem of health insecurity as the health of human person s depends upon nutrition, clear water and fresh air. Various environment related diseases. Deprived of a healthy environment, they have to adjust in the new place in absence of adequate living conditions. 
From the above analysis, it can be clearly observed that development in North-East India is a fruitless experience. It has served the interest of the selected few, but not of the general masses of the region.

\section{Conclusion}

Thus, the citizenship rights in a democratic country, like India is violated in the name of development. It violates their rights to live a life with human dignity. The development projects and programmes are generally carried out for the check of bringing development for the citizens to provide with better facilities of life. But the Indian experience of development have presented a complicated scenario with the violation of citizenship rights by depriving and displacing them from the place in which they are living since time immemorial and placing them in never ending problems and security issues. Thus, the issues of citizenship and development should be properly addressed and adequate attention should be paid to the demands and aspiration of the people.

\section{References}

[1] Acharya Amitav, Singdeo K Sudrat, Rajeretnan M, Human Security: From Concept To Practice-Case Study From North-East India and Orissa (World Scientific Publication, New Delhi, 2010)

[2] Bharali Gita, Development-Induced Displacement and Human Security in Assam (Department of Political Science, Gauhati University, 2006)

[3] Hussain Monirul, Interrogating Development: State, Displacement and Popular Resistance In north-East India (SAGE Publication Pvt. Ltd, New Delhi, 2008)

[4] Dutta Akhil Ranjan (edit), Human Security In North-East India: Issues and Policies (Anwesha Publication, Guwahati, 2008)

[5] Fernandez Walter, Rehabilitation Policy For The Displaced, Economic and Political Weekly, Volume 39, Issue 12, March 20, Pp-1191-1193, 2004 